\title{
EPSON (EARLY DETECTION FOR PARKINSON DISEASE) TINJAUAN PUSTAKA DISBIOSIS GUT MICROBIAL SEBAGAI POTENSI DETEKSI DINI PARKINSON MELALUI PEMERIKSAAN FESES
}

\author{
Qanita Adzkia Novindra' ${ }^{1}$, Fildzah Ghaisani Alifah² ${ }^{2}$ Nadia Alfi Syarifah ${ }^{3}$ \\ Program Studi Pendidikan Dokter, Fakultas Kedokteran dan Ilmu Kesehatan, Universitas Maulana Malik Ibrahim Malang
}

\begin{abstract}
Abstrak
Parkinson disease (PD) merupakan salah satu penyakit neurodegeneratif yang tidak dapat disembuhkan dengan manifetasi klinis berupa gangguan pada gerak motorik. Saat ini diagnosis pada penyakit parkinson masih didasarkan pada gejala motorik yang timbul. Deteksi dini pada PD dibutuhkan sehingga pasien akan mendapat penanganan sejak dini untuk mencegah patogenesis kerusakan neuron di substansia nigra. Berdasarkan penelitian, diketahui bahwa gejala berupa disfungsi usus muncul 5-7 tahun sebelum terjadi gangguan motorik pada pasien PD. Timbulnya disfungsi usus ini memiliki keterkaitan dengan ketidak seimbangan komposisi mikrobiota usus (GM). Tujuan dari literatur review ini adalah melakukan studi literatur mengenai hubungan antara komposisi GM dengan patogenesis parkinson disease sebagai dasar deteksi dini parkinson disease. Metode yang digunakan dalam proses literature review ini adalah metode PRISMA, dimana dari 261 sumber awal yang sudah penulis dapatkan sesuai dengan keyword menggunakan metode Boolean, terdapat 229 sumber yang di eksklusi karena tidak memenuhi kriteria inklusi yang ditetapkan penulis. Dari hasil dan pembahasan didapatkan bahwa disbiosis bakteri pada gastrointestinal tract adalah proses yang mengawali patogenesis dari PD. Hal ini dibuktikan dengan adanya peningkatan dua kali lipat konsentrasi Indoxyl Sulfat urin (indikator disbiosis mikroba) pada pasien. Terdapat pola unik perubahan komposisi mikroba saluran pencernaan, yaitu perubahan $\beta$ - diversity, peningkatan pertumbuhan koloni bakteri genus Akkermansia, Genus Lactobacillus, dan Famili Enterobacteriaceae; dan penurunan pertumbuhan Genus Faecalibacterium, dan Genus Provotella. Kesimpulan yang didapatkan adalah perubahan komposisi bakteri di saluran pencernaan merupakan salah satu pemicu yang mengawali patogenesis PD dan bahwa pola unik perubahan komposisi gut microbial memiliki potensi untuk dijadikan deteksi dini Parkinson Disease.
\end{abstract}

Kata Kunci: Parkinson disease, Gut Microbial, Disbiosis, Early Detection

\begin{abstract}
Parkinson's disease (PD) is a neurodegenerative disease that cannot be cured with clinical manifestations in the form of disturbances in motor movement. Currently the diagnosis of Parkinson's disease is still based on motor symptoms that arise. Early detection of $P D$ is needed so that patients will receive early treatment to prevent pathogenesis of neuronal damage in the substantia nigra. Based on research, it is known that the symptoms of intestinal dysfunction appear 5-7 years before motor problems occur in PD patients. The onset of intestinal dysfunction is related to an imbalance in the composition of the intestinal microbiota $(G M)$. The aim of this literature review is to conduct a literature study regarding the relationship between GM composition and the pathogenesis of Parkinson's disease as a basis for early detection of Parkinson's disease. The method used in this literature review process is the PRISMA method, where from the 261 initial sources that the author has obtained in accordance with the keywords using the Boolean method, 229 sources are excluded because they do not meet the inclusion criteria set by the author. From the results and discussion, it was found that bacterial dysbiosis in the gastrointestinal tract is a process that initiates the pathogenesis of PD. This is evidenced by a twofold increase in the urine concentration of Indoxyl Sulfate (an indicator of microbial dysbiosis) in patients. There is a unique pattern of changes in the microbial composition of the digestive tract, namely changes in $\beta$-diversity, increased growth of bacterial colonies of the Akkermansia genus, Lactobacillus, and Enterobacteriaceae; and decreased growth of Genus Faecalibacterium and Genus Provotella. The conclusion is that changes in the composition of bacteria in the digestive tract are one of the triggers that initiate the pathogenesis of PD and that the unique pattern of changes in microbial gut composition has the potential to be used as early detection of Parkinson's Disease.
\end{abstract}

Keywords: Parkinson's disease, Gut Microbial, Dysbiosis, Early Detection 


\section{PENDAHULUAN}

Parkinson disease (PD) merupakan salah satu penyakit neurodegeneratif yang tidak dapat disembuhkan dengan manifetasi klinis berupa gangguan pada gerak motorik. Dimana manifestasi klinis ini bersifat progresif sehingga dapat menurunkan kualitas hidup pasien.

PD merupakan penyakit neurodegeneratif yang memiliki prevelensi tertinggi kedua setelah Alzeimer. Penyakit ini menyerang 160 dari 100.000 populasi manusia, terutama pada laki-laki berusia lanjut. Penyakit parkinson umumnya baru diketahui ketika muncul gejala klinis berupa gangguan gerak motorik pada pasien.

Munculnya gangguan motorik ini terkait dengan patogenesis dari $\alpha$-synuclein missfolded yang beragregasi membentuk lewy bodies pada substansia nigra di saraf pusat. Adanya akumulasi lewy bodies ini menyebabkan kerusakan neuron dopanergik di substansia nigra sehingga akan terjadi degenerasi kadar dopamin secara masif.

Manifestasi klinis berupa gangguan motorik ini baru muncul ketika terjadi kerusakan neuron di substansia nigra sebesar lebih dari 60-70 persen.

Manifestasi klinis atau gejala yang menandai munculnya Penyakit Parkinson antara lain tremor saat istirahat, rigiditas, bradikinesia atau kelambanan gerak dan bicara, serta hilangnya reflex postural.

Saat ini diagnosis pada penyakit parkinson masih didasarkan pada gejala motorik yang timbul. Dimana seseorang dapat dikatakan kemungkinan mengidap PD apabila memenuhi dua dari empat gejala utama yang telah disebutkan atau memiliki salah satu dari bradikinesia, tremor saat istirahat dan rigiditas. Sedangkan untuk mendiagnosis bahwa suatu pasien dapat dipastikan mengidap penyakit parkinson apabila memiliki tiga dari empat gejala utama atau memiliki dua dari bradikinesia, tremor saat istirahat dan rigiditas.

Dari sini dapat terlihat bahwasanya PD baru terdiagnosis ketika sudah terjadi kerusakan neuron sebesar 60-70 persen pada substansia nigra. Wilayah yang cukup luas mengingat sifat perkembangan PD yang progresif.

Deteksi dini pada PD dibutuhkan sehingga pasien akan mendapat penanganan sejak dini untuk mencegah patogenesis kerusakan neuron di substansia nigra.

Berdasarkan penelitian, diketahui bahwa salah satu gejala klinis non- motorik dari PD adalah disfungsi usus. Dimana ditemukan $75 \%$ dari pasien PD mengalami sembelit [4] dan gangguan pengosongan lambung.

Gejala berupa disfungsi usus muncul 5- 7 tahun sebelum terjadi gangguan motorik pada pasien PD. Timbulnya disfungsi usus ini memiliki keterkaitan dengan ketidak seimbangan komposisi mikrobiota usus (GM). Dimana mikrobiota ini dapat menjadi biomarker dan pemicu kerusakan neuroenterik dengan menghasilkan $\alpha$-synuclein yang nantinya menyebar ke otak dan berkembang menjadi PD. Patogenesis ini terkait dengan ditemukannya hubungan antara GM di usus dengan otak.

Dari latar belakangan tersebut, penulis memiliki hipotesis bahwa terdapat kolerasi antara komposisi GM di usus dengan patologi PD dan adanya potensi komposisi GM untuk menjadi biomarker deteksi dini penyakit PD.

Tujuan dari literatur review ini adalah untuk melakukan studi literatur mengenai hubungan antara komposisi GM usus dengan patologi parkinson disease sebagai dasar deteksi dini parkinson disease.

\section{METODE}

Metode yang digunakan dalam proses literature review ini adalah metode PRISMA, dimana dari 261 sumber awal yang sudah penulis dapatkan sesuai dengan keyword "Parkinson", "neurodegenerative disease", "microbialchange", "Gut brain axis", "fecal", menggunakan metode Boolean, terdapat 229 sumber yang di eksklusi karena tidak memenuhi kriteria inklusi yang ditetapkan penulis. Sehingga didapatkan 32 jurnal akhir 
yang dijadikan referensi untuk kepenulisan literature review ini.

\section{HASIL PEMBAHASAN}

\section{a. Hubungan Perubahan Mikrobiota GI dengan Patogenesis PD}

Mikrobiota usus (GM) memiliki peran penting dalam fungsi usus, metabolisme dan siklus energi. GM juga diketahui memiliki efek pada hasil neurologis melalui mekanisme produksi metabolit dan sumbu usus - otak (GBA).

Saat ini banyak bukti secara bertahap yang mengidikasikan bahwa patogenesis pada beberapa penyakit neurologi seperti penyakit Alzeimer, deperesi, Multiple Sclerosis dan Parkinson disebabkan oleh disbiosis (pergeseran komposisi bakteri) GM.

Karakteristik patologis dari PD adalah adanya akumulasi protein $\alpha$-synuclein yang mengalami missfolding sehingga membentuk agregasi yang disebut dengan badan lewy, tepatnya di substansia nigra.

Beberapa penelitian pada tikus menunjukkan bahwa bentuk missfolded $\alpha$ synuclein menyebar dari saluran gastrointestinal ke otak. Hal ini mendukung hipotesis bahwa patogenesis PD dapat bertindak terutama melalui usus.

Hipotesis ini semakin diperkuat oleh penelitian dari Braak et al yang menggunakan survei postmortem pada 5 pasien PD dengan keparahan berbeda, yaitu 3 pasien dengan diagnosis PD klinis dan 2 pasien tanpa gejala klinis.

Dimana dari penelitian ini didapatkan kesimpulan bahwa inklusi $\alpha$-synuclein dapat ditemukan di pleksus mienterikus dan submukosa pada pasien PD yang bergejala maupun tidak bergejala. penelitian ini juga menunjukkan adanya bukti rute perkembangan PD yang berawal dari gastrointestinal karena ditemukannya inklusi $\alpha$-synuclein pada bagian saraf- saraf lain sesuai tahap perkembangan PD. Menurut Braak et al, penyebab patogenesis dari PD di gastrointestinal (GI) adalah bakteri neurotropik. bakteri neurotropik tersebut bisa berasal dari bakteri patogen dari lingkungan luar maupun bakteri komensal usus.

Disbiosis bakteri pada GI inilah yang mengawali patogenesis dari PD. Hal ini dibuktikan dengan adanya peningkatan dua kali lipat konsentrasi Indoxyl Sulfat urin (indikator disbiosis mikroba) pada pasien PD.

Disbiosis bakteri berperan dalam patogenesis PD melalui 2 jalur, yaitu jalur persarafan vagus (langsung) dan jalur peredaran darah (tidak langsung).

1) Patogenesi Jalur Persarafan Vagus.

Disbiosis mikroba menyebabkan peningkatan permeabilitas dari epitel usus, dimana disbiosis ini mempengaruhi tight junction antar sel epitel dengan mengurangi ekspresi dari protein okludin (protein transmembran) sehingga akan merenggangkan ikatan antar sel epitel usus dan menyebabkan peningkatkan permeabilitas bahkan kebocoran usus.

Terjadinya peningkatan permeabilitas usus akan memudahkan bakteri untuk masuk dan menginfeksi jaringan di usus. Masuknya bakteri kedalam jaringan di usus akan memicu pengaktifan respon inflamasi. Hal ini dapat disebabkan oleh adanya LPS di permukaan bakteri atau toksin yang dihasilkan oleh bakteri.

Respon inflamasi yang terjadi secara terus menerus akan menyebabkan salah satu mediator inflamasi yaitu makrofag untuk terus mengeluarkan bahan-bahan yang dapat merusak jaringan yang salah satunya berupa oksigen reaktif. Oksigen reaktif ini apabila terus terakumulasi maka akan menyebabkan stress oksidatif yang selanjutnya dapat menyebabkan terjadinya missfolding pada protein $\alpha$-synuclein.

Apabila bakteri dapat masuk ke daerah persarafan enterik (ENS) maka akan terjadi gangguan keseimbangan dari mukus pada saluran GI. Hal ini akan menurunkan sistem protektif saluran GI dan memudahkan bakteri untuk menginfeksi. Sehingga akan memperparah inflamasi lokal dan stress oksidatif pada saluran GI. 
Di saluran GI, missfolding-protein $\alpha$ synuclein dapat terbentuk langsung di persarafan enterik (neuroenterik) maupun di jaringan lain (dalam jumlah sedikit).

Missfolding protein $\alpha$-synuclein yang terbentuk di ENS akan merambat dan mencapai substansia nigra (CNS) melalui persarafan vagal dengan cara endositosis retrogradely antar saraf. Hal ini akan menyebabkan penumpukan missfolding-protein $\alpha$-synuclein sehingga terbentuklah badan lewy di substansia nigra.

Pernyataan ini didasarkan atas penelitian dari Holmqvist, et al pada tahun 2014 yang menyuntikan missfolding-protein $\alpha$-synuclein dari pasien PD ke dinding usus tikus. Dua hari setelah injeksi ditemukan missfolding-protein $\alpha$-synuclein di saraf vagus, dan enam hari setelah injeksi ditemukan missfolding-protein $\alpha$-synuclein di batang otak tikus. Hal ini menunjukkan adanya perambatan missfoldingprotein $\alpha$-synuclein ke nukleus motorik dorsal melalui saraf vagus tergantung waktu.

Selain melalui mekanisme tersebut, ditemukannya gagasan Gut-Brain Axis (GBA) oleh Sudo et al pada tahun 2004 menambah pengetahuan mengenai hubungan saluran GI dengan patogensis $\mathrm{PD}$.

Patogenesis PD jalur GBA berawal dari adanya stress lingkungan atau sinyal proinflamasi dari saluran GI. Sinyal ini dikenali dan dihantarkan oleh saraf vagus (sensor metabolit mikrobiota) ke otak. Sumbu hipotalamus-hipofisis-adrenal di aktifkan sebagai respon untuk sinyal tersebut. Hipotalamus mensekresikan hormon CRH yang memicu adenohipofisis untuk mensekresikan hormon ACTH yang akan memicu korteks adrenal untuk melepaskan hormon kortisol ke aliran darah sistemik, diantaranya ke otak dan usus. Di otak dan usus, hormon kortisol akan menyebabkan stress oksidatif sehingga memicu terjadinya missfolding pada protein $\alpha$-synuclein yang mengawali patogenesis PD.

\section{2) Patogenesis Jalur Peredaran Darah} Selain melalui jalur sensorik saraf vagal, GBA dapat berkomunikasi dengan mikrobiota usus melalui jalur peredaran darah. Mikrobiota usus berkomunikasi dengan GBA dengan mengeluarkan molekul persinyalan (mediator bakteri) yang akan melintasi epitel usus, bergerak melalui peredaran darah dan menembus Blood-Brain Barier (BBB) dan mencapai CNS. Kemudian dilanjutkan dengan mekanisme sumbu HPA yang sama dengan jalur GBA yang telah di jelaskan sebelumnya.

Sekresi kortisol yang berlebihan secara terus menerus akan meningkatkan laju metabolisme tubuh dan akhirnya menyebabkan stress pada mitokondria dan juga gliogenesis. Stress yang terjadi terus menerus akan menjadi stress kronik. Stress kronik ini akan menyebabkan pengeluaran sitokin seperti TNF- $\alpha$ yang dapat menyebabkan perubahan oksidatif dan aktivasi NFkb yang menginduksi terbentuknya senyawa pro-inflamasi (iNOS, NOS-2, dan COX-2). Inflamasi yang terjadi akan semakin memperbanyak akumulasi ROS dalam jaringan tubuh sehingga pada akhirnya akan menyebabkan terjadinya protein misfolding.

Terjadinya protein misfolding menyebabkan protein $\alpha$-synuclein yang awalnya berikatan secara stabil menjadi mudah untuk beragregasi satu sama lain membentuk badan lewy [18]. Selanjutnya, agregasi badan lewy ini menyebabkan hilangnya neuron dopaminergik di subtansia nigra yang merupakan awal dari munculnya gejala-gejala klinis motorik yang biasanya terjadi pada pasien parkinson. 


\section{b. Biomarker PD Ditinjau dari Perubahan Mikrobiota di Saluran GI}

Tabel 1. Rangkuman hasil dari 12 studi microbiota feses pada pasien PD dibandingkan dengan kontrol yang sehat.



Keterangan : $+=$ meningkat $\quad-=$ menurun $\square$ =sample fass $\square$ sample jar. kolon 
Berdasarkan studi literatur yang telah dilakukan oleh penulis dihasilkan tabel yang menyajikan temuan dari 12 studi yang berfokus pada pengamatan mikrobiota usus pada pasien parkison dibandingkan dengan kontrol yang sehat (tabel 1). 12 penelitian tersebut menggunakan sample feses (1 penelitian menggunakan 2 jenis sample, feses dan jaringan usus) dari pasien parkison dengan durasi sakit dibawah +/- 10 tahun, terhitung sejak didiagnosis berdasarkan kriteria dignosis dari UK PD society Bank Brain ditinjau dari gangguan gerak motorik. Seluruh penelitian menggunakan teknik lab basah sekuensing 16 rRNA yaitu teknik identifikasi yang kuat dalam studi mikrobiota.

Untuk mengetahui komposisi mikrobiota usus sebagai biomarker PD pada feses, penulis meninjau mikrobiota berdasarkan keragaman dan jumlah terbanyak kesamaan pola pertumbuhan koloni bakteri (meningkat atau menurun) pada kedua belas penelitian, kemudian peneliti meninjau patogenesis PD dari daftar bakteri yang sudah didapatkan dari tahapan sebelumnya untuk mencocokkan pola pertumbuhan bakteri pada PD dengan patogenesis yang disebabkannya.

Penelitian mengenai keragaman (diversity) dari mikrobiota di usus masih terbatas. Dari 12 penelitian yang terpilih, hanya 8 penelitian (I,III,IV, V,VI,XI,X,XI) yang melakukan pengamatan terhadap keragaman (diversity) mikroba pada usus pasien PD. Keragaman yang diteliti adalah $\alpha$-diversity dan $\beta$-diversity.

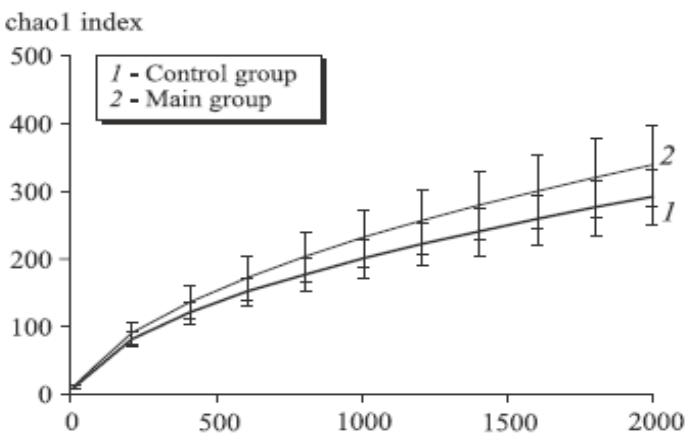

Gambar 2. grafik $\alpha$-diversity kelompok pasien PD dan kontrol
Dari 8 studi yang mengamati diversity bakteri di usus, hanya 3 penelitian (III,IX,XI) yang menunjukkan adanya perbedaan signifikan dalam $\alpha$-diversity, yaitu kekayaan dan kerataan komunitas dalam sample feses dari kelompok pasien PD dan kontrol (gambar 1)

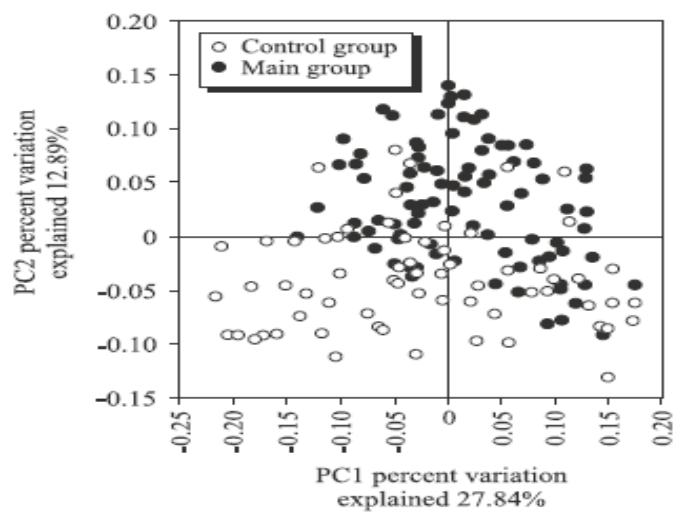

Gambar 3. PCoA plot $\beta$-diversity pasien PD dan kontrol.

Sedangkan untuk $\beta$-diversity, yaitu perbedaan komunitas antar kelompok studi menunjukkan adanya perubahan yang signifikan pada kedelapan penelitian (I, III, IV, V, VI, XI, X, XI).

Jarak antar titik pada PcoA plot menunjukkan derajat kedekatan taksonomi antar mikroba (gambar 2). Semakin berkurang jaraknya, maka semakin dekat pula hubungan taksonomi antar mikroba dan sebaliknya. Terlihat adanya penurunan jarak antar titik pada pasien $\mathrm{PD}$, hal ini menunjukkan penurunan pada $\beta$-diversity, artinya bakteri-bakteri di saluran pencernaan pada pasien PD memiliki kedekatan taksonomi. Selain itu, adanya penurunan $\beta$-diversity mengindikasikan terjadinya disbiosis yang berhubungan dengan terjadinya inflamasi pada saluran GI yang menjadi pemicu missfolding protein $\alpha$ synuclein.

Terjadinya disbiosis mengindikasi terjadinya perubahan komposisi mikrobiota pada saluran GI. Hal ini ditunjukkan pada tabel 1 , yang memuat perubahan komposisi berbagai mikrobiota di usus dari sample feses pada 12 penelitian terpilih. Dari tabel tersebut penulis 
mendapatkan lima mikrobiota dengan jumlah kesaman pola pertumbuhan koloni terbanyak. Bakteri dengan peningkatan pertumbuhan yaitu Genus Akkermansia, Genus Lactobacillus, dan Famili Enterobacteriaceae. Sedangkan bakteri dengan penurunan pertumbuhan adalah Genus Faecalibacterium, dan Genus Provotella.

Berdasarkan hasil pengkajian dari berbagai penelitian ditemukan fakta bahwa bakteri yang mengalami peningkatan pertumbuhan koloni adalah bakteri proinflamasi dan bakteri yang berfungsi dalam mekanisme adaptif disbiosis. Peningkatan bakteri Akkermensia pada feses pasien PD terkait dengan perannya yang menperkuat barrier gastrointestinal dan stimulus imun anti inflamasi. Dimana hal ini merupakan mekanisme adaptif untuk mengatasi infeksi dan inflamasi sebagai dampak disbiosis di saluran GI yang biasanya mengawali patogenesis PD.

Genus Lactobacillus kurang lebih memiliki mekanisme adaptasi yang hampir sama dengan Akkermansia dalam mengalami penambahan jumlah di saluran gastrointestinal pasien PD yaitu sebagai dampak adaptif dari disbiosis bakteri lebih tepatnya karena adanya pengurangan dari Provotella yang merupakan bakteri anti- inflamatori. Hal ini dapat dikaitkan dengan fungsi Lactobacillus yang berperan sebagai pereduksi sitokin pro- inflamatori.

Enterobacteriaceae merupakan flora normal yang berada di saluran usus manusia yang dapat menyebabkan infeksi oportunistik. Peningkatan Enterobactericeae berkolerasi dengan peningkatan permabilitas dari saluran GI yang dapat meningkatkan kerentanan saluran GI terhadap inflamasi dan missfolding $\alpha$-synuclein berhubungan postif dengan tingkat. Selain itu, kelimpahan relatif Enterobacteriaceae keparahan ketidakstabilan postural dan kesulitan gaya berjalan pada pasien PD.

Sedangkan bakteri yang mengalami penurunan pertumbuhan koloni adalah bakteri anti-inflamasi. Diketahui bahwa bakteri Faecalibacterium dan Protovella menghasilkan butirat sebagai produk metabolismenya. Butirat merupakan salah satu senyawa Short Chain
Fatty Acid (SCFA), yang mengerahkan tindakan anti-inflamasi melalui mekanisme epigenetik atau aktivasi reseptor SCFA. Sehingga apabila terjadi penurunan terkait bakteri ini maka dapat menyebabkan penurunan kadar SCFA dan pada akhirnya kebocoran usus yang akan meningkatkan resiko terjadinya infeksi oleh bakteri dan missfolding $\alpha$ synuclein.

Dengan demikian adanya pola perubahan komposisi mikrobiota usus yang unik ini memiliki potensi untuk menjadi biomarker deteksi dini PD Protovotella.

\section{KESIMPULAN DAN SARAN}

Perubahan komposisi bakteri di saluran pencernaan merupakan salah satu pemicu yang mengawali patogenesis PD dengan menyebabkan terbentuknya missfolding $\alpha$ synuclein melalui jalur persarafan vagus atau peredaran darah, yang kemudian akan terakumulasi di sunbstansia nigra yg dan menyebabkan terganggunya produksi dopamin sehingga timbul manifestasi klinis PD.

Pola unik perubahan komposisi mikroba saluran pencernaan, yaitu perubahan $\beta$ diversity, peningkatan pertumbuhan koloni bakteri genus Akkermansia, Genus Lactobacillus, dan Famili Enterobacteriaceae; dan penurunan pertumbuhan Genus

Faecalibacterium, dan Genus memiliki potensi untuk menjadi biomarker deteksi dini PD.

Kajian biomarker ini perlu untuk dikaji lebih dalam lagi, karena saat ini penelitian mengenai analisis perubahan komposisi mikrobiota pada pasien Parkinsos masih sangat terbatas dan masih belum ada penelitian jenis Kohort yang mengikuti perjalanan perubahan komposisi mikrobiota pasien dengan gangguan usus hingga terdiagnosis PD, sehingga sampai saat ini masih banyak terdapat pertanyaan dan penafsiran mengenai biomarker ini.

Kajian dan penelitian ini juga perlu dikembangkan dengan meninjau perubahan mikrobiota terkait dengan tingkat keparahan Parkinson. 


\section{DAFTAR PUSTAKA}

1. Gunawan G, Dalhar M, Kurniawan SN. Parkinson And Stem Cell Therapy. Malang Neurology Journal. 2017 ; 3 :39-46. doi: 10.21776/ub.mnj.2017.003.01.7

2. Forsythe P, Kunze WA. Voices from within:gut microbes and the CNS. Cell Mol Life Sci. 2013; 70:55-69 doi: $10.1007 / \mathrm{s} 00018-012-1028-\mathrm{z}$

3. Samuels AM. Manual of Neurologi Therapeutics. Philadeplhia: Lippincott Williams \& Walkins : 2017

4. Gao, Xiang, et al. A prospective study of bowel movement frequency and risk of Parkinson's disease. American journal of epidemiology. 2011; 174(5): 546551.doi:10.1093/aje/kwr119

5. Mulak A, Bonaz B. Brain-Gut-Microbiota Axis in Parkinson's Disease. World J Gastroenterol. 2015; 21:10609-20.doi: 10.3748/wjg.v21.i37.10609.

6. Yang, Dongming, et al. The Role of the GuMicrobiota in the Pathogenesis of Parkinson's Disease. Frontiers in neurology. 2019; $10 \quad$ : $1-13$ doi: 10.3389/fneur.2019.01155

7. Spielman, Lindsay Joy; Gibson, Deanna Lynn; Klegeris, Andis. Unhealthy Gut, Unhealthy Brain: The Role Of The Intestinal Microbiota In Neurodegenerative Diseases. Neurochemistry international. 2018; 120:149-163.doi:

10.1016/j.neuint.2018.08.005

8. Holmqvist, Staffan, Et Al. Direct Evidence Of Parkinson Pathology Spread from The Gastrointestinal Tract to The Brain in Rats.Acta Neuropathologica. 2014; 128(6): 805-20 doi :10.1007/s00401-014-1343-6

9. Braak H, Vos Raid, Bohl J, Tredici KD. Inclusions in Meissner's And Auerbach's Plexuses in Cases Staged For Parkinson's Disease-Related Brain Pathology. Neurosci Lett. 2006; 396:67-72. doi: 10.1016/J.Neulet.2005.11.012

10.Cassani, Erica, et al. Increased Urinary Indoxyl Sulfate (Indican): New Insights into
Gut Dysbiosis in Parkinson's Disease. Parkinsonism \& Related Disorders. $2015 ; 21(4) \quad$ : $\quad 389-393 \quad$ doi: 10.1016/j.parkreldis.2015.02.004

11.Baratawidjaja, Karnen G., Rengganis, Iris. Imunologi Dasar Edisi ke Sebelas. Jakarta: Balai Penerbit FKUI : 2014. h 336-337

12.SNCA gene synuclein alpha [internet].National Library of Medicine.. 2020 [cited 30 juni 2020]. Available from:http://www.nlm.nih.gov/medlineplus/ hantavirusinfections.html

13.Guyton, A. C., Hall, J. E. Buku Ajar Fisiologi Kedokteran. Edisi 13. Jakarta : EGC: 2019. h1022.

14.Herath, M., Hosie, S., Bornstein, J. C., Franks, A. E., \& Hill-Yardin, E. L. The Role of the Gastrointestinal Mucus System in Intestinal Homeostasis: Implications for Neurological Disorders. Frontiers in Cellular and Infection Microbiology. 2020; 10: 248. doi:10.3389/fcimb.2020.00248

15.Chen Peng (ed.). Gut Microbiota and Pathogenesis of Organ Injury. Springer Singapore. : 2020.

16.Zulissetiana, Eka Febri; Suryani, Puji Rizki. Degenerasi Kognitif pada Stres Kronik. Jurnal Kedokteran Universitas Lampung. 2016; 1(2): 418-423.

17.Lisdiana. Regulasi Kortisol Pada Kondisi Stres dan Addiction. Biosantifika. 2012; 4(1) :18- 26.

18.Bartels, T., Choi, J. G., \& Selkoe, D. J. $\alpha-$ Synuclein occurs physiologically as a helically folded tetramer that resists aggregation.Nature. 2011; 477(7362): 107110.doi : 10.1038/nature10324

19.Holmqvist, S., Chutna, O., Bousset, L., Aldrin Kirk, P., Li, W., Björklund, T., Wang, Z. Y., Roybon, L., Melki, R., \& Li, J. Y. Direct evidence of Parkinson pathology spread from the gastrointestinal tract to the brain in rats. Acta neuropathologica. 2014; 128(6): 805-820 doi: 10.1007/s00401-0141343-6

20.Keshavarzian, Ali, et al. Colonic Bacterial Composition in Parkinson's Disease. 
Movement Disorders. 2015; 30(10) :13511360. doi : $10.1002 / \mathrm{mds} .26307$

21.Gerhardt, Sara; Mohajeri, M. Hasan. Changes of Colonic Bacterial Composition in Parkinson's Disease and Other Neurodegenerative Diseases. Nutrients. 2018;10(6) : 708 doi: 10.3390/nu10060708

22.Petrov, V. A., et al. Analysis of Gut Microbiota

inPatientswithParkinson'sDisease. Bulletin of Experimental biology and medicine. 2017;162(6): 734-737.doi: 10.1007/s10517017-3700-7

23.Li, Wei, et al. Structural Changes of Gut Microbiota in Parkinson's Disease and Its Correlation with Clinical Features. Science China Life Sciences. 2017; 60(11): 12231233. doi: 10.1007/s11427-016-9001-4

24.Hill-Burns, Erin M., et al. Parkinson's Disease And Parkinson's Disease Medications Have Distinct Signatures of The Gut Microbiome. Movement Disorders. 2017; 32(5): 739-749. doi: $10.1002 /$ mds. 26942

25.Bedarf, Janis R., et al. Functional Implications of Microbial and Viral Gut Metagenome Changes in Early Stage LDOPA-Naïve Parkinson's Disease Patients. Genome medicine. 2017; 9(1) : 1-1 doi: 10.1186/s13073-017-0428-y

26.Unger, Marcus M., et al. Short Chain Fatty Acids and Gut Microbiota Differ between Patients with Parkinson's Disease and AgeMatched Controls. Parkinsonism \& related disorders. 2016; 32: 66-72 doi: 10.1016/j.parkreldis.2016.08.019

27.Heintz-Buschart, Anna, et al. The nasal and gut microbiome in Parkinson's disease and idiopathic rapid eye movement sleep behavior disorder. Movement disorders, 2018, 33.1: 88- 98. doi: 10.1002/mds. 27105

28.Lin $\mathrm{CH}$, et al. Altered gut microbiota and inflammatory cytokine responses in patients with Parkinson's disease. J Neuroinflammation. 2019;16:129. doi: 10.1186/s12974-019-1528-y

29.Li, Fang, et al. Alteration of the fecal microbiota in North-Eastern Han Chinese population with sporadic Parkinson's disease. Neuroscience letters. 2019; 707:134297.doi:

10.1016/j.neulet.2019.134297

30.Scheperjans, Filip, et al. Gut microbiota are related to Parkinson's disease and clinical phenotype.Movement Disorders, 2015, 30.3:350-358. doi: 10.1002/mds.26069

31.Kowalska-Duplaga, Kinga, et al. Differences in the intestinal microbiome of healthy children and patients with newly diagnosed Crohn's disease. Scientific reports. 2019; 9(1): 1-11. dos:10.3389/fnmol.2019.00171

32.Magistrelli, Luca et al. "Probiotics May Have Beneficial Effects in Parkinson's Disease: In vitro Evidence."Frontiers in immunology vol. 10 969. 7 May. 2019, doi: 10.3389/fimmu.2019.00969 